\title{
Türkiye Dış Ticaretinin Kümeleme Analizi ile İncelenmesi
}

\begin{abstract}
Türkiye Dış Ticaretinin Kümeleme Analizi ile İncelenmesi
Öz

Gelişmekte olan ülkeler arasında bulunan Türkiye'nin küreselleşme ile birlikte dış ticareti artmaktadır. Bu çalışmada Türkiye'nin ihracat ve ithalat yaptığı ülkelerin kümelere ayrılması amacıyla, Wards ve k-ortalamalar kümeleme yöntemleri kullanılmıştır. Veri seti Birleşmiş Milletler resmî web sitesinden elde edilirken, değişken olarak SITC Rev. 3 basamak 1 mal sınıflandırması kullanılmıştır. İthalat ve ihracat bağlamında yapılan analizlerde 3 ve 4 küme sayısına göre üyelikler elde edilmiştir. Buna göre Türkiye'ye mesafe olarak uzak olan veya küçük nüfuslu ülkeler sayıca en kalabalık kümeyi oluşturmaktadır. İthalatta Almanya, ABD, Birleşik Krallık, Çin, Brezilya ve Rusya, ihracatta ise Almanya, Fransa, İran, İsrail, İtalya, Hollanda, Suudi Arabistan, İspanya, BAE, Mısır, Birleşik Krallık, ABD ve Irak'ın diğer ülkelerden ayrışmaktadır. Ayrıca bu ülkelerden Irak ihracatta, Rusya ise ithalatta tek başına birer küme oluşturmaktadır.
\end{abstract}

Anahtar Kelimeler: Dış Ticaret, Kümeleme Analizi, Ward Kümeleme Yöntemi, k-ortalama Kümeleme Yöntemi

\author{
Investigation of Turkey's Foreign Trade Using Cluster \\ Analysis
}

Abstract

Turkey's, which is among the developing countries, foreign trade is increasing with the globalization. In this study, Wards and k-means clustering methods were used to divide the countries that Turkey exports and imports into clusters. While the data set was obtained from the United Nations official website, SITC Rev. 3 level 1 codes were used as variables. In the analyzes made in the context of import and export, memberships were obtained according to the number of 3 and 4 clusters. In this respect, countries that are distant from Turkey or with small populations constitute the most crowded cluster. Germany, USA, UK, China, Brazil and Russia in import and Germany, France, Iran, Israel, Italy, Netherlands, Saudi Arabia, Spain, UAE, Egypt, the United Kingdom, the USA and Iraq in export separated other countries. In addition, Iraq in exports and Russia in imports have formed a cluster on their own.

Keywords: Foreign Trade, Cluster Analysis, Wards Clustering Method, k-means Clustering Method

\section{Giriş}

Dünya toplumları kültür, coğrafya, tarih, nüfus, sosyal, siyasi, ekonomi, vb. yapılar açısından birbirlerinden farklı olmalarına rağmen, hiçbir ülke tamamıyla içe kapanık ve diğer toplumlarla paylaşımdan uzak yaşayamamaktadır. Bunun en açık göstergeleri ülkelerin bir araya gelerek oluşturdukları Birleşmiş Milletler, Avrupa Birliği, OECD vb. kuruluşlardır. Diğer taraftan günümüzde ülkeler arasındaki ekonomik ilişkiler, diğer yapılardan daha fazla öneme sahiptir. Çoğu zaman ekonomik nedenlerden kaynaklı sorunların savaşlara neden olduğu da görülmektedir. Bu bağlamda ülkelerin dış dünya ile yaptığı mal alım ve satımları şeklinde tanımlanan dış ticarette söz sahibi olmaları, ekonomik açıdan güçlerini göstermektedir. Ayrıca 1980'lerde küreselleşme çerçevesinde iletişim ve haberleşme teknolojilerinde yaşanan gelişmeler, ülkelerin iç piyasalar üzerine koydukları kısıtlamaları göreceli olarak kaldırmaları piyasaları birleştirici etki yaratmıştır. Küreselleşme ticaret ve üretimi küresel hale getirirken, rekabetin daha fazla önem kazanmasına neden olmuştur. Diğer taraftan gelişmekte olan ülkelerin büyük çoğunluğu artan dış borç yükü ve adaletsiz ticaret koşulları altındadır. Gelişmekte olan ülkelerin, gelişmiş ülkelere yapacakları ihracatlar bu ülkelerin kısıtlayıcı politikalarıyla engellenmektedir. Gelişmekte

\footnotetext{
${ }^{1}$ Yrd. Doç. Dr., Anadolu Üniversitesi, İktisadi ve İdari Bilimler Fakültesi, İşletme Bölümü, dcoskun@anadolu.edu.tr

${ }^{2}$ Arş. Gör., Anadolu Üniversitesi, İktisadi ve İdari Bilimler Fakültesi, ahmetaytekin@anadolu.edu.tr
} 
olan ülkelerin gelişmiş ülkelere eşdeğer refah düzeyini yakalayabilmeleri ve kalkınabilmeleri için dış ticaret çok önemli bir role sahiptir (Seyidoğlu, 2007: 1-4).

Gelişmekte olan ülkeler arasında bulunan Türkiye'nin dış ticaret hacmi genel olarak artış eğilimindedir. 1923 yılında dış ticaret hacmi ihracatta 50.790 dolar, ithalatta 86.872 dolar iken, Cumhuriyetin 50. yılında bu rakamlar ihracatta 1.317.083 dolara, ithalatta ise 2.086.216 dolara ulaşmıştır. İhracat hacminin rekor seviyesi 2014 yılında 157.610 .158 dolardır. İthalat ise rekor seviyeye 2013 yılında 251.661.250 dolar ile ulaşmıştır. Diğer taraftan Türkiye'nin ihracatı, ithalatını en son 1946 yılında geçmiş ve bu yılda ihracatın ithalatı karşılama oranı \%180,5 olmuştur. 2016 yılı dış ticaret hacmi 341.162.085 dolar (ihracat 142.545.946 ve ithalat 198.616.139 dolar) gerçekleşmiştir ${ }^{3}$. Bu bağlamda Türkiye'nin dış ticaret açığı veren ekonomik yapıya sahip olduğu görülmektedir. Türkiye'nin kalkınma düzeyini arttırabilmesi için katma değeri yüksek mallar ihraç etmesi ve pazar çeşitliliğini arttırması gerekmektedir.

Bu çalışmada Türkiye'nin 2016 yılında ihracat ve ithalat yaptığı ülkelerin kümelere ayrılmasıyla dış ticaretinin açıklayıcı bir resminin elde edilmesi amaçlanmaktadır. Çalışmada Birleşmiş Milletler resmi veri tabanından elde edilen SITC (Uluslararası Standart Ticaret Sınıflaması) Rev.3 basamak 12016 verileri kullanılmıştır. Tablo 1'de verilen SITC Rev.3 basamak 1 mal sınıflandırma kodları, değişkenler olarak belirlenmiş ve gösterim kolaylığı sağlanması amacıyla kısaltılmıştır.

Tablo 1: SITC Rev.3 Basamak 1 Sinıflandırması

\begin{tabular}{cll}
\hline Mal Sınıfı Numarası & Mal Sınıfı İsmi & Kısa Gösterimi \\
\hline \hline 1 & Canlı hayvanlar ve gıda maddeleri & $\mathrm{S}_{0}$ \\
2 & İçki ve tütün & $\mathrm{S}_{1}$ \\
3 & Akaryakıt hariç yenilenemeyen hammaddeler & $\mathrm{S}_{2}$ \\
4 & Mineral yakıtlar, yağlar ve alkali ürünler & $\mathrm{S}_{3}$ \\
5 & Hayvansal, bitkisel katı ve sıvı yağlar, mumlar & $\mathrm{S}_{4}$ \\
6 & Başka yerde belirtilmeyen kimya sanayi ve ürünleri & $\mathrm{S}_{5}$ \\
7 & Başlıca sınıflara ayrılan işlenmiş mallar & $\mathrm{S}_{6}$ \\
8 & Makineler ve taşıt araçları & $\mathrm{S}_{7}$ \\
9 & Çeşitli mamul eşya & $\mathrm{S}_{8}$
\end{tabular}

Kaynak: BM Uluslararası Ticaret İstatistikleri Veritabanı (Comtrade)

SITC, Birleşmiş Milletler tarafından uluslararası karşılaştırmada kolaylık sağlamak amacıyla tavsiye edilmektedir. SITC, hükümetlerin iş birliği ve uzmanların görüşleri alınarak hazırlanmaktadır. Diğer taraftan dış ticarette yaşanan gelişmeler nedeniyle dört kez revize edilmiştir. SITC'de birden beşe doğru basamaklı bir yapı bulunmaktadır. Tablo 1'de görüleceği üzere basamak 1'de 10 adet mal sınıfı yer almaktadır. Basamak 2'de 67, basamak 3'de 261, basamak 4'de 1033 ve basamak 5'de 3121 adet mal sınıfı bulunmaktadır (TÜiK, 2008). Çalışmada SITC Rev.3 basamak 1 mal sınıflaması bağlamında elde edilen veriler kullanılmıştır.

\footnotetext{
${ }^{3}$ www.tuik.gov.tr/PrelstatistikTablo.do?istab_id=621 (Erişim Tarihi: 16.04 .2017 )
} 
Kümeleme analizi ile Türkiye'nin dış ticaretinin farklı değişkenlerle değerlendirildiği çalışmalar bulunmaktadır. Akyüz (2006) Türkiye'nin orman ürünleri sanayi sektörü ve Gümrük Birliği (GB) bağlamında dış ticaret potansiyelini ve konumunun belirlemeyi amaçlamış, GB'nin levha sanayi gelişimine olumlu katkı sağladığı ve bu alanda Türkiye'nin rekabet gücünün arttığı, kâğıt ve kereste sanayini ise olumsuz etkilediğini ifade etmiştir. Bircan vd. (2006), Türkiye'nin ihracat yaptığı ülkeleri SOM tipi yapay sinir ağları kullanarak yirmi beş kümeye ayırmış, ticaretin yoğun olduğu ülkelerin ayrı kümelendiğini belirtmiştir. Bulum vd. (2013), ülkeleri ihracat, ithalat ve nüfus verilerini dikkate alarak gruplara ayırmış, ABD’nin diğer ülkelerden ayrışarak tek başına bir küme oluşturduğunu ifade etmiştir. Kantar vd. (2011), minimum yayılan ağaç, hiyerarşik ağaç ve ortalama bağlantı yöntemleriyle Türkiye ile ihracat ve ithalat yapan ülkeleri incelemiş; Almanya, Birleşik Krallık (Ingiltere), Fransa, İtalya ve Rusya'nın diğer ülkelerle kuvvetli bağları olması nedeniyle öne çıktıklarını ifade etmiştir. Tiryaki vd. (2015), Türkiye ve AB üyesi ülkelerin mobilya sektörü ihracat ve ithalat değerlerini Kümeleme Analiziyle gruplandırmayı amaçlamış ve Türkiye'nin ithalat ve ihracat hacminde orta sıralarda bulunduğunu ifade etmiştir (Tiryaki vd., 2015). Uygur (2013) Türkiye'nin dış ticaret ve doğrudan yatırım ilişkisi içerisinde olduğu ülkeleri ithalat, ihracat ve doğrudan yatırım değerlerini değişken olarak kullanıp Kümeleme Analizi ile gruplandırmış, ihracat açısından İran, Almanya ve Irak'ın; ithalat açısından ise Almanya ve Çin'in diğer ülkelerden ayrışarak tek başına birer küme oluşturduklarını belirtmiştir.

Söz konusu çalışmalar incelendiğinde, dış ticarette genel olarak Türkiye'nin diğer ülkeler arasındaki konumunun araştırıldığı veya sadece ihracat ya da ithalat verileriyle analiz yapıldığı görülmektedir. Bu çalışmada Türkiye'nin penceresinden dış ticaret ilişkisinde olduğu ülkeler kümelenmesi ihracat ve ithalat verileri açısından ayrı olarak yapılmıştır. Ayrıca hiyerarşik kümeleme yöntemlerinden Ward ve hiyerarşik olmayan kümeleme yöntemlerinde k-ortalama kullanılarak sonuçların karşılaştırıması sağlanmıştır. Bu bağlamda çalışmanın literatüre yeni bir bakış açısı kazandıracağı düşünülmektedir. Diğer taraftan genel bir kümeleme yapılabilmesi ve geçerli değere sahip ülke sayısı açısından SITC Rev. 3 Basamak 1 verileri kullanılarak analizler gerçekleştirilmiştir. İzleyen bölümde çalışmada kullanılan yöntem olan Kümeleme Analizine yer verilmiştir.

\section{Kümeleme Analizi}

Kümeleme analizi, değişkenleri veya birimleri sahip oldukları özelliklere göre benzer kümelere veya gruplara ayırmayı sağlayan bir grup çok değişkenli istatistik yöntemidir (Hair vd.,2014: 418). Kümeleme analizi, benzer amaçlarla kullanılabilen faktör analizinden gözlemleri kümelere ayırması, diskriminant ve lojistik regresyon analizlerinden küme/grup özelliklerinin bilinmemesi ve analiz süresince birimlerin küme üyeliklerinin değişebilmesine olanak sağlaması gibi nedenlerden dolayı ayrışmaktadır. Ayrıca bu yöntemlerden farklı olarak kümeleme analizinde benzerlik ve uzaklık ölçüleri kullanılmaktadır.

Kümeleme analizinde, normallik, doğrusallık, sabit varyanslılık gibi varsayımlara diğer çok değişkenli istatistik teknikleri kadar önem verilmemektedir. Örneklemin anakütleyi temsil etmesi ve değişkenler arasında çoklu bağıntı olmaması yeterli görülmektedir (Alpar, 2013: 320).

Literatürde Kümeleme Analizinin birçok açıdan sınıflandırması yapılmakla birlikte genel olarak hiyerarşik ve hiyerarşik olmayan kümeleme yöntemleri olarak iki ana grupta değerlendirildiği görülmektedir.

Hiyerarşik yöntemler, birimlerin kümelere ayırılması bağlamında değerlendirildiğinde; $n$ birim sayısı olmak üzere birimleri bir hiyerarşiye ya da bir ağaç yapısına dönüştüren bir dizi $n$ - 1 
kümeleme kararını içermektedir. Hiyerarşik kümeleme birleştirici ve bölücü olmak üzere iki temel sınıfa ayrılmaktadır. Birleştirici yöntemler, her gözlemin kendisinin bir küme oluşturmasıyla başlar. Daha sonra aynı anda iki en benzer kümenin birleştirilmesi biçiminde ilerler ve tek bir küme oluşturuluncaya dek kümeler bir araya getirilir. Birleştirici yöntemler arasında tek bağlantı, tam bağlantı, ortalama bağlantı, Ward, medyan merkezileştirme ve centroid yöntemleri bulunmaktadır. Bölücü yöntemlerde ise tüm birimleri içeren tek bir küme ile başlar ve her biri tek üyeli bir küme olana kadar ilk önce iki kümeye, sonra üç ve benzeri kümeye ardışık bölünmeyle sona erer. Bölücü yöntemler arasında bölünmüş ortalamalar ve otomatik etkileşim belirleme yöntemleri yer almaktadır (Çokluk vd., 2014: 141-142, Hair vd.,2014: 439-442).

Hiyerarşik olmayan yöntemler, hiyerarşik yöntemlerin aksine aşamalı süreçleri içermez. Bunun yerine, küme sayısı belirlendikten sonra gözlemler kümelere atanır. En yaygın kullanılan hiyerarşik olmayan yöntemler k-ortalama, medoid, bulanık ve yığma kümeleme yöntemleridir (Özdamar, 2013: 295).

Kümeleme analizi yöntemlerinin incelenmesi bu çalışmanın amaçları arasında yer almamaktadır. Çalışmada, küme sayısı ile ilgili teorik bilgi bulunmaması, belirli bir küme sayısının olmaması nedeniyle öncelikle hiyerarşik kümeleme yöntemi uygulanmasına karar verilmiştir. Hiyerarşik kümeleme yöntemlerinden Ward yöntemi farklı varyans yapısına sahip birimleri küme içi değişkenliği en küçükleyecek şekilde kümelere ayırması nedeniyle tercih edilmiştir. Ayrıca kümeleme sonuçlarının karşılaştırılabilmesi amacıyla hiyerarşik olmayan yöntemlerden k-ortalama yöntemi kullanılmıştır. Ward ve k-ortalama yöntemleri izleyen kısımlarda açıklanmıştır.

\subsection{Ward Bağlantı Kümeleme Yöntemi}

Ward bağlantı yöntemi, hiyerarşik kümelemede varyans analizi yaklaşımını içermektedir. İki kümenin birleştirilmesinde olası birleşimler için hataların kareli toplamındaki artış hesaplanarak, artışı en küçükleyecek bağlantı seçilmekte ve kümeleme gerçekleştirilmektedir (Akpınar, 2014: 308; Hair vd.,2014: 442). Ward yöntemi ile kümelemede eşitlik (1)'den yararlanılmaktadır. Bu eşitlikte; $N$ ilgili kümenin eleman sayısı, $m$ iki kümenin birleştirilmesiyle oluşacak yeni küme, k ve I daha önce oluşturulan kümeleri ve j bunlarla birleşime girecek kümeyi, $d_{m j} m$. kümenin j. küme ile olan uzaklığını göstermektedir (Özdamar, 2013: 273).

$$
d_{m j}=\frac{\left(\left(N_{j}+N_{k}\right) d_{k j}+\left(N_{j}+N_{l}\right) d_{j j}-N_{j} d_{k l}\right)}{\left(N_{j}+N_{m}\right)}
$$

Ward's yönteminde uzaklık ölçüsü olarak kareli veya mutlak Öklit uzaklığı ölçüsünün kullanılması önerilmektedir (Hair vd., 2014: 431). Diğer taraftan değişkenlerin farklı ölçüm birimlerine sahip olması veya değişkenliklerinin farklı olması durumunda veri standardize edilmekte veya logaritmik dönüşüme tabi tutulmaktadır. Aksi takdirde büyük ortalama ve varyansa sahip olan değişkenler diğer değişkenleri baskılamaktadır. Bu durumda standardizasyonu sağlamak amacıyla en az aralıklı ölçekle elde edilmiş ve normal dağılıma sahip veriler z dönüşümüyle, değişim genişliği çok farklı olan değişkenler değişim genişliğine göre, heterojen yapıda ve negatifpozitif aşırı uç değerlere sahip veriler $-1 \leq x \leq+1$ aralığına göre, sadece pozitif aşırı uç değerlere sahip veri $0 \leq x \leq 1$ aralığına göre dönüştürülebilmektedir. Ayrıca aynı ölçü birimine sahip ve aşırı sağa çarpık kesikli veriye sahip serilere logaritmik dönüşüm uygulanabilmektedir (Aydın vd., 2015: 184; Özdamar, 2013: 266-268).

Çalışmada Ward bağlantı yönteminin uygulanması amacıyla öncelikle verilerin değişim aralığına göre standardizasyonu eşitlik (2) yardımıyla gerçekleştirilmiştir. Daha sonra standardize değerler eşitlik (3) ile hesaplanan Kareli Öklid Uzaklığının elde edilmesinde kullanılmıştır. 


$$
\begin{aligned}
& X=\frac{x_{i}}{x_{\text {maks }}-X_{\text {min }}} \\
& d_{i j}=\sum_{k=1}^{p}\left(X_{i k}-X_{j k}\right)^{2}
\end{aligned}
$$

Eşitlik (2) ve (3)'de $n$ birim sayısı olmak üzere $i=1, \ldots, n$ ve $j=1, \ldots, n^{\prime}$ dir. Ayrıca $p$ değişken sayısını olmak üzere, $k=1, \ldots, p^{\prime}$ dir. $d_{i j}$ i. ve j. birimler arasındaki Kareli Öklid Uzaklığıdır.

İzleyen kısımda hiyerarşik olmayan yöntemlerden k-ortalama yönteminin açıklamalarına yer verilmiştir.

\section{2. k-ortalama Yöntemi}

k-ortalama yöntemi N birimden oluşan veri setini, küme içi kareler toplamını en küçükleyecek biçimde önceden belirlenen sayıya göre kümelere ayırmaktadır. Bu işlemin gerçekleştirilebilmesi için öncelikle başlangıç küme merkezi/çekirdek noktaları seçilmektedir. Daha sonra bu merkezi noktalara göre yinelemeli/iteratif olarak birimlerin kümelere ataması yapılmaktadır. Merkezi noktalar veri setinde bulunan değerlerden seçilebileceği gibi olasılık kurallarına göre de seçilebilmektedir. Atama işlemleri amaç fonksiyonunun, küme içi değiş̧kenliğin en az ve kümeler arası değişkenliğin en fazla olduğu maksimizasyonun sağlanması ile son bulmaktadır. Bu maksimizasyonu sağlamak amacıyla eşitlik (4)'den yararlanılmaktadır. Eşitlik (4)'de k küme sayısını, $x_{c j} c$. kümeye ait j. birim, $m_{c} c$. kümenin merkezi, $N_{c} c$. kümenin birim sayısını göstermektedir. Bu bağlamda bir iterasyonda a kümesine atanan bir birim, sonraki iterasyonda başka bir kümeye atanabilmektedir (Aydın vd, 2015: 187; Özdamar, 2013: 296).

$$
\sum_{\mathrm{c}=1}^{\mathrm{k}} \sum_{\mathrm{j}=1}^{\mathrm{N}_{\mathrm{c}}}\left\|\mathrm{x}_{\mathrm{cj}}-\mathrm{m}_{\mathrm{c}}\right\|^{2}
$$

k-ortalamalar yönteminde küme sayısının belirlenmesi amacıyla farklı yaklaşımlardan yararlanılmaktadır. Bu yaklaşımların içerisinde en pratik olanı eşitlik (5) ile elde edilen küme sayısıdır.

$$
k \cong \sqrt{N / 2}
$$

Eşitlik (5) ile elde edilen küme sayısı büyük örneklemler için iyi sonuç vermemektedir. Bu nedenle W grup içi kareler toplamı matrisi olmak üzere eşitlik (6) ile elde edilen en küçük $M$ değerini veren küme sayısı kullanılmaktadır (Tatlıdil, 2002, s. 341-342).

$$
M=k^{2}|W|
$$

Bu yaklaşımların dışında birçok farklı yaklaşım bulunmakla birlikte hiyerarşik kümeleme yöntemleri uygulanarak elde edilen sonuçlar yorumlanıp küme sayısına karar verilebilir ve belirlenen küme sayısından hareketle k-ortalama yöntemi uygulanabilir. Ayrıca teorik olarak birimlerin ayrılması beklenen küme sayısı ile ilgili bilgi varsa küme sayısı buna göre de belirlenebilmektedir.

Çalışmanın izleyen bölümünde Türkiye'nin dış ticaret ilişkisi içerisinde olduğu ülkeler öncelikle Ward yöntemiyle ihracat ve ithalat bağlamında ayrı olarak kümelere ayrılmışırı. Ardından k-ortalama yöntemiyle aynı işlem tekrarlanmıştır. Son olarak ihracat ve ithalat kümeleri karşılaştırılarak değerlendirmeler yapılmış ve kümelemede etkili değişkenler belirlenmiştir. 


\section{Uygulama}

Bu bölümde Birleşmiş Milletler resmi veri tabanından elde edilen 2016 yılı SITC (Uluslararası Standart Ticaret Sınıflaması) Rev.3 basamak 1 verileri kullanılarak Türkiye'nin ihracat ve ithalat yaptığı ülkelerinin kümelere ayrılması amaçlanmıştır ${ }^{4}$.

Analizler SPSS 24 paket programı ile gerçekleştirilmiştir. Küme sayısı ile ilgili teorik bilgi bulunmaması, belirli bir küme sayısının olmaması nedeniyle öncelikle hiyerarşik kümeleme yöntemlerinden Wards yöntemi kullanılmıştır. İhracat ve ithalat rakamlarının değişken bazında değişiminin çok büyük olması sebebiyle uzaklıklar hesaplanmadan önce veriye standardizasyon uygulanmıştır. Böylelikle herhangi bir değişkenin baskın olması engellenmiştir. Analize geçilmeden önce değişkenler arasında çoklu bağıntı olup olmadığının incelenmesi amacıyla korelasyon değerleri kontrol edilmiş ve 0,90 ' un üstünde korelasyona sahip değişken olmadığı görülmüştür.

Çalışmanın izleyen kısmında öncelikle Ward kümeleme yöntemiyle Türkiye'nin ihracat ve ithalat kümelemesi yapılmış, daha sonra aynı işlem k-ortalamalar yöntemiyle gerçekleştirilmiştir. İhracat için geçerli veriye sahip 128 ülke, ithalat için 73 ülke analize dâhil edilmiştir. Bu durum Türkiye'nin ihracat yaptığı ülke çeşitliliğinin ithalata göre daha fazla olduğunu göstermektedir. Ward yöntemi uygulanmadan önce uzaklık ölçüsü olarak Karesel Öklid Uzaklığı seçilmiştir. Ward yöntemi ile ihracat verileriyle yapılan analiz sonucunda elde edilen dendogram ve birleştirme tablosundaki gözlemler arasındaki mesafeyi gösteren katsayılar incelenerek uygun küme sayısının 3 olduğuna karar verilmiştir. Diğer taraftan ihracat ve ithalat kümelerinin birlikte yorumlayabilmek amacıyla hem 3 hem de 4 küme sayısına göre üyelikler elde edilmiştir. İhracat ve ithalat verileri bağlamında Ward yöntemiyle elde edilen Türkiye'nin dış ticaret küme üyelikleri Tablo 2'de verilmiştir.

Tablo 2: Ward Kümeleme Sonuçları

\begin{tabular}{|c|c|c|c|}
\hline $\begin{array}{l}\text { Küme } \\
\text { Sayısı }\end{array}$ & $\begin{array}{l}\text { Küme } \\
\text { Nu- } \\
\text { ma- } \\
\text { rası }\end{array}$ & İhracat & İthalat \\
\hline$k=3$ & 1 & $\begin{array}{l}\text { Avusturya, Avustralya, Bosna-Hersek, Bre- } \\
\text { zilya, Şili, Hırvatistan, Çekya, Danimarka, Fin- } \\
\text { landiya, Yunanistan, Hong Kong, Macaristan, } \\
\text { İzlanda, Endonezya, İrlanda, Japonya, Kaza- } \\
\text { kistan, Ürdün, Kenya, Kuveyt, Kırgızistan, Lüb- } \\
\text { nan, Litvanya, Malezya, Meksika, Moldova, } \\
\text { Karadağ, Umman, Nijerya, Norveç, Pakistan, } \\
\text { Portekiz, Katar, Senegal, Sırbistan, Hindistan, } \\
\text { Singapur, Slovakya, Vietnam, Slovenya, Gü- } \\
\text { ney Afrika, Sudan, İsveç, Tayland, Tunus, Uk- } \\
\text { rayna, Makedonya, Afganistan, Arnavutluk, } \\
\text { Angola, Arjantin, Bahreyn, Bangladeş, Kam- } \\
\text { boçya, Kamerun, Sri Lanka, Kolombiya, } \\
\text { Kongo, Demokratik Kongo, Benin, Dominik, } \\
\text { Etiyopya, Gabon, Gambiya, Filistin, Gana, } \\
\text { Gine, Guyana, Honduras, Fildişi Sahili, Jama- } \\
\text { ika, Letonya, Liberya, Libya, Maldivler, Mali, } \\
\text { Malta, Moritanya, Moritus, Moğolistan, Cu- }\end{array}$ & $\begin{array}{l}\text { Avusturya, Avustralya, Bosna-Hersek, Ka- } \\
\text { nada, Şili, Hırvatistan, Çekya, Danimarka, } \\
\text { Finlandiya, Yunanistan, Hong Kong, Macaris- } \\
\text { tan, Endonezya, İrlanda, Japonya, Kazakis- } \\
\text { tan, Ürdün, Kenya, Kuveyt, Kırgızistan, Lüb- } \\
\text { nan, Litvanya, Malezya, Meksika, Moldova, } \\
\text { Karadağ, Umman, Nijerya, Norveç, Pakistan, } \\
\text { Portekiz, Katar, Senegal, Sırbistan, Hindistan, } \\
\text { Singapur, Slovakya, Vietnam, Slovenya, Gü- } \\
\text { ney Afrika, Sudan, İsveç, Tayland, Tunus, Uk- } \\
\text { rayna, Makedonya, Azerbaycan, Belçika, Bul- } \\
\text { garistan, Fransa, Gürcistan, İsrail, İtalya, Gü- } \\
\text { ney Kore, Fas, Polonya, Romanya, Suudi Ara- } \\
\text { bistan, İspanya, İsviçre, Suriye, BAE, Mısır, } \\
\text { İran, Irak, Estonya, Zimbabwe. }\end{array}$ \\
\hline
\end{tabular}

${ }^{4}$ https://comtrade.un.org/data/ (Erişim tarihi: 16.03.2017) 


\begin{tabular}{|c|c|c|c|}
\hline & & $\begin{array}{l}\text { raçao, Yeni Zelanda, Nijer, Panama, Peru, Fili- } \\
\text { pinler, Seyşeller, Sierra Leone, Somali, Suri- } \\
\text { nam, Tacikistan, Togo, Uganda, Tanzanya, } \\
\text { Burkina Faso, Uruguay, Venezuela, Yemen, } \\
\text { Zambiya. }\end{array}$ & \\
\hline & 2 & $\begin{array}{l}\text { Cezayir, Azerbaycan, Belçika, Bulgaristan, Çin, } \\
\text { Fransa, Gürcistan, İsrail, İtalya, Güney Kore, } \\
\text { Fas, Hollanda, Polonya, Romanya, Rusya, Su- } \\
\text { udi Arabistan, İspanya, İsviçre, Suriye, BAE, } \\
\text { Türkmenistan, Mısır, Özbekistan. }\end{array}$ & $\begin{array}{l}\text { Brezilya, Çin, Hollanda, Almanya, Birleşik } \\
\text { Krallık, ABD. }\end{array}$ \\
\hline & 3 & Almanya, İran, Irak, Birleşik Krallık, ABD. & Rusya. \\
\hline$k=4$ & 1 & $\begin{array}{l}\text { Avusturya, Avustralya, Bosna-Hersek, Ka- } \\
\text { nada, Şili, Hırvatistan, Çekya, Danimarka, Fin- } \\
\text { landiya, Yunanistan, Hong Kong, Macaristan, } \\
\text { Endonezya, İrlanda, Japonya, Kazakistan, Ür- } \\
\text { dün, Kenya, Kuveyt, Kırgızistan, Lübnan, Lit- } \\
\text { vanya, Malezya, Meksika, Moldova, Umman, } \\
\text { Nijerya, Norveç, Pakistan, Portekiz, Katar, Se- } \\
\text { negal, Sırbistan, Hindistan, Singapur, Slo- } \\
\text { vakya, Vietnam, Slovenya, Güney Afrika, Su- } \\
\text { dan, İsveç, Tayland, Tunus, Ukrayna, Make- } \\
\text { donya, Brezilya, Afganistan, Arnavutluk, An- } \\
\text { gola, Arjantin, Bahreyn, Bangladeş, Kam- } \\
\text { boçya, Kamerun, Sri Lanka, Kolombiya, } \\
\text { Kongo, Demokratik Kongo, Benin, Dominik, } \\
\text { Etiyopya, Gabon, Gambiya, Filistin, Gana, } \\
\text { Gine, Guyana, Honduras, İzlanda, Fildişi Sahili, } \\
\text { Jamaika, Letonya, Liberya, Libya, Maldivler, } \\
\text { Mali, Malta, Moritanya, Moritus, .Moğolistan, } \\
\text { Curaçao, Yeni Zelanda, Nijer, Panama, Peru, } \\
\text { Filipinler, Seyşeller, Sierra Leone, Somali, Su- } \\
\text { rinam, Tacikistan, Togo, Uganda, Tanzanya, } \\
\text { Burkina Faso, Uruguay, Venezuela, Yemen, } \\
\text { Zambiya. }\end{array}$ & $\begin{array}{l}\text { Avusturya, Avustralya, Bosna-Hersek, Ka- } \\
\text { nada, Şili, Hırvatistan, Çekya, Danimarka, } \\
\text { Finlandiya, Yunanistan, Hong Kong, Macaris- } \\
\text { tan, Endonezya, İrlanda, Japonya, Kazakis- } \\
\text { tan, Ürdün, Kenya, Kuveyt, Kırgızistan, Lüb- } \\
\text { nan, Litvanya, Malezya, Meksika, Moldova, } \\
\text { Umman, Nijerya, Norveç, Pakistan, Portekiz, } \\
\text { Katar, Senegal, Sırbistan, Hindistan, Sing- } \\
\text { pur, Slovakya, Vietnam, Slovenya, Güney Af- } \\
\text { rika, Sudan, İsveç, Tayland, Tunus, Ukrayna, } \\
\text { Makedonya, Azerbaycan, Belçika, Bulgaris- } \\
\text { tan, Fransa, Gürcistan, İsrail, İtalya, Güney } \\
\text { Kore, Fas, Polonya, Romanya, Suudi Arabis- } \\
\text { tan, İspanya, İsviçre, Suriye, BAE, Mısır, İran, } \\
\text { Irak, Estonya, Zimbabwe. }\end{array}$ \\
\hline & 2 & $\begin{array}{l}\text { Azerbaycan, Belçika, Bulgaristan, Çin, Fransa, } \\
\text { Gürcistan, İsrail, İtalya, Güney Kore, Fas, Hol- } \\
\text { landa, Polonya, Romanya, Rusya, Suudi Ara- } \\
\text { bistan, İspanya, İsviçre, Suriye, BAE, Mısır, } \\
\text { Hollanda, Cezayir, Türkmenistan, Özbekistan. }\end{array}$ & Brezilya, Hollanda, Birleşik Krallık, ABD. \\
\hline & 3 & Almanya, İran, Birleşik Krallık, ABD. & Almanya, Çin. \\
\hline & 4 & Irak. & Rusya. \\
\hline
\end{tabular}

Tablo 2'de yer alan ithalat kümeleme sonuçları ABD, Almanya, Birleşik Krallık, Brezilya, Çin, Hollanda ve Rusya'nın diğer ülkelerden ayrıştığını göstermektedir. Bu ülkelerden Rusya küme sayısı hem 3 hem de 4 olarak belirlendiğinde tek başına bir küme oluşturmaktadır. İhracat kümelemesinde ise küme sayısı 3 olarak belirlendiğinde ABD, Almanya, Birleşik Krallık, Irak ve İran diğer ülkelerden ayrışmakta iken küme sayısı 4 olduğunda Irak'ın bu ülkelerden ayrı küme oluşturduğu görülmektedir.

Tablo 2'de, ihracat kümelemesinde 2. kümede yer alan Rusya ithalat kümelemesinde tek başına 3. kümeyi oluşturmaktadır. Rusya, Türkiye'nin en çok ithalat yaptığı 3. ülke konumunda iken, ihracat sıralamasında ilk 10'da yer almamaktadır. Bu durumun Türkiye'nin özellikle enerji 
konusundaki dışa bağımlılığından kaynaklandığı anlaşılmaktadır. Özellikle mineral yakıtlar, yağlar ve alkali ürünler (S3) sınıfında tek taraflı bir ticaret akışından söz etmek mümkündür. Türkiye'nin Rusya'dan ithalat hacmi taş kömürü, kok kömürü, biriket kömürü (32) mal sınıfından; 1.009.504.184 dolar, petrol ve petrolden elde edilen ürünler (33) mal sınıfından; 2.169.449.362 dolar, elektrik enerjisi (35) mal sınıfından 229.670.227 dolardır. Diğer taraftan bu mal sınıflarının tamamından Rusya'ya ihracatı sadece 15.540.021 dolardır. Bir diğer çarpıcı sonuç ise ithalata göre diğer ülkelerden çok fazla ayrışmayan Irak'ın ihracatta tek başına küme oluşturmasıdır. Benzer durum Azerbaycan, Gürcistan, İran, Suriye gibi komşu ülkeler için de söz konusudur. Türkiye'nin komşuları ile ticaretinin ne kadar önemli olduğunun göstergesi olarak değerlendirilebilecek bu durum, aynı zamanda son dönemde Orta Doğu'da yaşanan sorunların Türkiye'nin dış ticareti üzerindeki olumsuz etkisinin ortadan kalkması halinde bu ülkelerin, Türkiye'nin ihracatında olumlu rol oynayacağını işaret etmektedir. Ayrıca Çin, Türkiye'nin ithalatında ilk sırada yer alırken ihracat sıralamasında ilk 50'ye girmemektedir. Çin, Türkiye'nin S6, S7 ve S8 değişkenleri bağlamında en çok ithalat yaptığı ülke konumundadır ${ }^{5}$.

Ward yöntemiyle yapılan kümeleme analizinde değişkenlerin işleme alınıp alınmadığının ve kümeler arasında anlamlı fark olup olmadığının incelenmesi amacıyla varyans analizi yapıımış ve sonuçlar Tablo 3'te verilmiştir.

Tablo 3: Ward Kümeleme Yöntemi Iç̧in ANOVA Tablosu

\begin{tabular}{|c|c|c|c|c|c|c|c|c|c|c|c|c|}
\hline & \multicolumn{6}{|c|}{ İhracat Kümeleri } & \multicolumn{6}{|c|}{ İthalat Kümeleri } \\
\hline & \multicolumn{3}{|c|}{$k=3$} & \multicolumn{3}{|c|}{$k=4$} & \multicolumn{3}{|c|}{$k=3$} & \multicolumn{3}{|c|}{$k=4$} \\
\hline Değ. & $\begin{array}{l}\text { KKO } \\
(\mathrm{sd}= \\
2)\end{array}$ & $\begin{array}{l}\text { HKO } \\
(s d= \\
125)\end{array}$ & $\mathrm{F}$ & $\begin{array}{l}\text { KKO } \\
\text { (sd = } \\
3 \text { ) }\end{array}$ & $\begin{array}{l}\text { НKO } \\
(s d=124)\end{array}$ & $\mathrm{F}$ & $\begin{array}{l}\text { KKO } \\
\text { (sd = } \\
2)\end{array}$ & $\begin{array}{l}\text { HKO } \\
(\mathrm{sd}= \\
70)\end{array}$ & $\mathrm{F}$ & $\begin{array}{l}\text { KKO } \\
\text { (sd = } \\
3)\end{array}$ & $\begin{array}{l}\text { HKO } \\
(\mathrm{sd}= \\
69)\end{array}$ & $\mathrm{F}$ \\
\hline $\mathrm{S}_{0}$ & 0,38 & 0,01 & $62,26 * * *$ & 0,40 & 0,00 & $170,57 * * *$ & 0,57 & 0,01 & $93,25 * * *$ & 0,38 & 0,01 & $61,38 * * *$ \\
\hline $\mathrm{S}_{1}$ & 0,85 & 0,01 & $95,74 * * *$ & 0,56 & 0,01 & $63,41 * * *$ & 0,91 & 0,01 & $77,83^{* * *}$ & 0,70 & 0,01 & $88,64 * * *$ \\
\hline $\mathrm{S}_{2}$ & 0,05 & 0,01 & $6,90 * *$ & 0,04 & 0,01 & $4,72 * * *$ & 0,47 & 0,01 & $48,08 * * *$ & 0,36 & 0,01 & $44,72 * * *$ \\
\hline $\mathrm{S}_{3}$ & 0,16 & 0,01 & $11,88 * * *$ & 0,11 & 0,01 & 8,01 & 0,47 & 0,01 & $75,74 * * *$ & 0,31 & 0,01 & $50,12 * * *$ \\
\hline $\mathrm{S}_{4}$ & 0,12 & 0,01 & $16,49 * * *$ & 0,33 & 0,00 & $326,91 * * *$ & 0,47 & 0,01 & $55,28 * * *$ & 0,32 & 0,01 & $36,33 * * *$ \\
\hline $\mathrm{S}_{5}$ & 1,14 & 0,01 & $219,47 * * *$ & 0,83 & 0,00 & $230,15^{* * *}$ & 0,31 & 0,02 & $15,44 * * *$ & 0,33 & 0,02 & $22,10 * * *$ \\
\hline $\mathrm{S}_{6}$ & 1,33 & 0,01 & $174,51 * * *$ & 0,89 & 0,01 & $119,44 * * *$ & 0,39 & 0,02 & $22,57 * * *$ & 0,48 & 0,01 & $57,31 * * *$ \\
\hline $\mathrm{S}_{7}$ & 0,54 & 0,01 & $56,85^{* * *}$ & 0,40 & 0,01 & $47,63 * * *$ & 0,36 & 0,02 & $21,53 * * *$ & 0,52 & 0,01 & $102,84 * * *$ \\
\hline $\mathrm{S}_{8}$ & 0,75 & 0,01 & $104,33 * * *$ & 0,50 & 0,01 & $69,09 * * *$ & 0,18 & 0,01 & $14,99 * * *$ & 0,28 & 0,01 & $52,01 * * *$ \\
\hline $\mathrm{S}_{9}$ & 0,24 & 0,01 & $23,00 * * *$ & 0,19 & 0,01 & $20,22 * * *$ & 0,47 & 0,01 & $38,64 * * *$ & 0,31 & 0,01 & $25,40 * * *$ \\
\hline
\end{tabular}

Tablo 3 incelendiğinde ihracat verileri için küme sayısı 4 olarak belirlendiğinde S3 değişkeninin kümeleme analizinde anlamlı etkiye sahip olmadığı, bu durumun haricinde tüm değişkenlerin ithalat ve ihracat verilerinin kümelenmesinde etkili olduğu görülmektedir.

K-ortalama kümeleme analizi sonuçları Tablo 4'te verilmiştir.

${ }^{5}$ https://comtrade.un.org/data/ (Erişim Tarihi: 14.04.2017) 
Aralık 2017, C. 12, S. 3

Tablo 4: k-ortalama Kümeleme Sonuçları

\begin{tabular}{|c|c|c|c|}
\hline $\begin{array}{l}\text { Küme } \\
\text { Sayısı }\end{array}$ & $\begin{array}{l}\text { Küme } \\
\text { Numa- } \\
\text { rası }\end{array}$ & İhracat & İthalat \\
\hline \multirow[t]{3}{*}{$k=3$} & 1 & $\begin{array}{l}\text { Çin, Rusya, Azerbaycan, Avusturya, Avustralya, } \\
\text { Belçika, Bosna-Hersek, Brezilya, Bulgaristan, } \\
\text { Kanada, Şili, Hırvatistan, Çekya, Danimarka, } \\
\text { Finlandiya, Gürcistan, Yunanistan, Hong Kong, } \\
\text { Macaristan, Endonezya, İrlanda, Japonya, Ka- } \\
\text { zakistan, Ürdün, Kenya, Güney Kore, Kuveyt, } \\
\text { Kırgızistan, Lübnan, Litvanya, Malezya, Mek- } \\
\text { sika, Moldova, Fas, Umman, Nijerya, Norveç, } \\
\text { Pakistan, Polonya, Portekiz, Katar, Romanya, } \\
\text { Senegal, Sırbistan, Hindistan, Singapur, Slo- } \\
\text { vakya, Vietnam, Slovenya, Güney Afrika, Su- } \\
\text { dan, İsveç, İsviçre, Suriye, Tayland, BAE, Tunus, } \\
\text { Ukrayna, Makedonya, Afganistan, Arnavutluk, } \\
\text { Cezayir, Angola, Arjantin, Bahreyn, Bangladeş, } \\
\text { Kamboçya, Kamerun, Sri Lanka, Kolombiya, } \\
\text { Kongo, Demokratik Kongo, Benin, Dominik, } \\
\text { Etiyopya, Gabon, Gambiya, Filistin, Gana, } \\
\text { Gine, Guyana, Honduras, Fildişi Sahili, Jamaika, } \\
\text { Letonya, Liberya, Libya, Maldivler, Mali, Malta, } \\
\text { Moritanya, Moritus, .Moğolistan, Curaçao, } \\
\text { Yeni Zelanda, Nijer, Panama, Peru, Filipinler, } \\
\text { Seyşeller, Sierra Leone, Somali, Surinam, Taci- } \\
\text { kistan, Togo, Türkmenistan, Uganda, Tan- } \\
\text { zanya, Burkina Faso, Uruguay, Özbekistan, Ve- } \\
\text { nezuela, Yemen, Zambiya. }\end{array}$ & Çin, Almanya. \\
\hline & 2 & $\begin{array}{l}\text { Almanya, Fransa, İran, İsrail, İtalya, Hollanda, } \\
\text { Suudi Arabistan, İspanya, BAE, Mısır, Birleşik } \\
\text { Krallık, ABD. }\end{array}$ & Rusya. \\
\hline & 3 & Irak. & $\begin{array}{l}\text { Azerbaycan, Avusturya, Avustralya, Belçika, } \\
\text { Bosna-Hersek, Brezilya, Bulgaristan, Kanada, } \\
\text { Şili, Hırvatistan, Çekya, Danimarka, Estonya, } \\
\text { Finlandiya, Fransa, Gürcistan, Yunanistan, } \\
\text { Hong Kong, Macaristan, Endonezya, İran, Irak, } \\
\text { İrlanda, İsrail, İtalya, Japonya, Kazakistan, Ür- } \\
\text { dün, Kenya, Güney Kore, Kuveyt, Kırgızistan, } \\
\text { Lübnan, Litvanya, Malezya, Meksika, Moldova, } \\
\text { Fas, Umman, Hollanda, Nijerya, Norveç, Pakis- } \\
\text { tan, Polonya, Portekiz, Katar, Romanya, Suudí, } \\
\text { Arabistan, Senegal, Sırbistan, Hindistan, Singa- } \\
\text { pur, Slovakya, Vietnam, Slovenya, Güney Af- } \\
\text { rika, Zimbabve, İspanya, Sudan, İsveç, İsviçre, } \\
\text { Suriye, Tayland, BAE, Tunus, Ukrayna, Make- } \\
\text { donya, Mısır, Birleşik Krallık, ABD. }\end{array}$ \\
\hline$k=4$ & 1 & Irak. & $\begin{array}{l}\text { Azerbaycan, Avusturya, Avustralya, Belçika, } \\
\text { Bosna-Hersek, Bulgaristan, Kanada, Şili, Hırva- } \\
\text { tistan, Çekya, Danimarka, Finlandiya, Gürcis- } \\
\text { tan, Yunanistan, Hong Kong, Macaristan, En- } \\
\text { donezya, İrlanda, Japonya, Kazakistan, Ürdün, } \\
\text { Kenya, Güney Kore, Kuveyt, Kırgızistan, Lüb- } \\
\text { nan, Litvanya, Malezya, Meksika, Moldova, }\end{array}$ \\
\hline
\end{tabular}


Fas, Umman, Nijerya, Norveç, Pakistan, Polonya, Portekiz, Katar, Romanya, Senegal, Sırbistan, Hindistan, Singapur, Slovakya, Vietnam, Slovenya, Güney Afrika, Sudan, İsveç, İsviçre, Suriye, Tayland, Tunus, Ukrayna, Makedonya, Fransa, İran, Irak, İsrail, İtalya, Suudi Arabistan, İspanya, BAE, Mısır, Estonya, Zimbabve.

\begin{tabular}{ll}
\hline 2 & Belçika, Bulgaristan, Polonya, Romanya, Brezilya, Hollanda, Birleşik Krallık, ABD. \\
Fransa, İran, İsrail, Suudi Arabistan, İspanya, \\
Mısır, Hollanda, Rusya. \\
\hline 3 Azerbaycan, Avusturya, Avustralya, Bosna- $\quad$ Almanya, Çin. \\
Hersek, Kanada, Şili, Hırvatistan, Çekya, Dani- \\
marka, Finlandiya, Gürcistan, Yunanistan, \\
Hong Kong, Macaristan, Endonezya, İrlanda, \\
Japonya, Kazakistan, Ürdün, Kenya, Güney \\
Kore, Kuveyt, Kırgızistan, Lübnan, Litvanya, \\
Malezya, Meksika, Moldova, Umman, Nijerya, \\
Norveç, Pakistan, Portekiz, Katar, Senegal, Sır- \\
bistan, Hindistan, Singapur, Slovakya, Viet- \\
nam, Slovenya, Güney Afrika, Sudan, İsveç, İs- \\
viçre, Tayland, Tunus, Ukrayna, Makedonya, \\
Brezilya, Çin, Afganistan, Arnavutluk, Cezayir, \\
Angola, Arjantin, Bahreyn, Bangladeş, Kam- \\
boçya, Kamerun, Sri Lanka, Kolombiya, Kongo, \\
Demokratik Kongo, Benin, Dominik, Etiyopya, \\
Gabon, Gambiya, Filistin, Gana, Gine, Guyana, \\
Honduras, İzlanda, Fildişi Sahili, Jamaika, Le- \\
tonya, Liberya, Libya, Maldivler, Mali, Malta, \\
Moritanya, Moritus, .Moğolistan, Karadağ, Cu- \\
raçao, Yeni Zelanda, Nijer, Panama, Peru, Fili- \\
pinler, Seyşeller, Sierra Leone, Somali, Suri- \\
nam, Tacikistan, Togo, Türkmenistan, Uganda, \\
Tanzanya, Burkina Faso, Uruguay, Özbekistan, \\
Venezuela, Yemen, Zambiya. \\
Almanya, ABD, Birleşik Krallık, İtalya. \\
\hline 4
\end{tabular}

Tablo 4 incelendiğinde $k$ = 4 için elde edilen k-ortalama yöntemi sonuçlarının Ward yöntemi ile elde edilen sonuçlara oldukça benzer olduğu görülmektedir. Diğer taraftan k-ortalama yönteminde ihracat için küme sayısı 3 olarak belirlendiğinde, Ward yönteminden farklı olarak ikinci kümede bulunan ülke sayısının arttığı görülmektedir. Bu durum kümeleme analizinin seçilen standardizasyon, uzaklık ölçüsü ve yöntem nedeniyle sonuçlarının farklılaşmasından kaynaklanmaktadır.

k-ortalama yöntemi ile yapılan kümeleme analizinde hangi değişkenlerin etkili olduğunun tespiti için varyans analizi yapıımış ve sonuçlar Tablo 5'de verilmiştir. 
Tablo 5: k-ortalama Kümeme Yöntemi İçin ANOVA Tablosu

\begin{tabular}{|c|c|c|c|c|c|c|c|c|c|c|c|c|}
\hline & \multicolumn{6}{|c|}{ İhracat Kümeleri } & \multicolumn{6}{|c|}{ İthalat Kümeleri } \\
\hline & \multicolumn{3}{|c|}{$k=3$} & \multicolumn{3}{|c|}{$\mathrm{k}=4$} & \multicolumn{3}{|c|}{$k=3$} & \multicolumn{3}{|c|}{$k=4$} \\
\hline $\begin{array}{l}\text { Değ } \\
\text {. }\end{array}$ & $\begin{array}{l}\text { KKO } \\
(\mathrm{sd}=2 \\
)\end{array}$ & $\begin{array}{l}\text { HKO } \\
(s d=12 \\
5)\end{array}$ & $\mathrm{F}$ & $\begin{array}{c}\mathrm{KK} \\
\mathrm{O} \\
(\mathrm{sd} \\
=3) \\
\end{array}$ & $\begin{array}{l}\text { HKO } \\
(\mathrm{sd}=12 \\
4)\end{array}$ & $\mathrm{F}$ & $\begin{array}{l}\text { KK } \\
O \\
(\mathrm{sd} \\
=2)\end{array}$ & $\begin{array}{l}\text { HKO } \\
(s d=70 \\
)\end{array}$ & $\mathrm{F}$ & $\begin{array}{l}\text { KK } \\
O \\
(s d \\
=3)\end{array}$ & $\begin{array}{l}\text { HKO } \\
(s d=69 \\
)\end{array}$ & $\mathrm{F}$ \\
\hline$S_{0}$ & 0,60 & 0,00 & $241,71 * *$ & 0,4 & 0,00 & $310,35^{* *}$ & 0,4 & 0,01 & $52,54 * * *$ & 0,3 & 0,01 & $61,38^{* * *}$ \\
\hline$\underline{S_{1}}$ & 0,60 & 0,01 & $46,63 * * *$ & 0,3 & 0,01 & $30,05 * * *$ & 0,0 & 0,04 & 1,68 & 0,7 & 0,01 & $88,64 * * *$ \\
\hline $\mathrm{S}_{2}$ & 0,01 & 0,01 & 1,2 & 0,0 & 0,01 & 1,34 & 0,1 & 0,02 & $5,60 * *$ & 0,3 & 0,01 & $44,72 * * *$ \\
\hline $\mathrm{S}_{3}$ & 0,34 & 0,01 & $32,31 * * *$ & 0,1 & 0,01 & $14,33 * * *$ & 0,4 & 0,01 & $75,66 * * *$ & 0,3 & 0,01 & $50,12 * * *$ \\
\hline $\mathrm{S}_{4}$ & 0,49 & 0,00 & $461,46^{* *}$ & 0,3 & 0,00 & $300,28 * *$ & 0,4 & 0,01 & $55,22 * * *$ & 0,3 & 0,01 & $36,33 * * *$ \\
\hline $\mathrm{S}_{5}$ & 0,92 & 0,01 & $107,11 * *$ & 0,6 & 0,01 & $100,49 * *$ & 0,4 & 0,02 & $27,88^{* * *}$ & 0,3 & 0,02 & $22,10 * * *$ \\
\hline $\mathrm{S}_{6}$ & 1,17 & 0,01 & $116,50 * *$ & 1,0 & 0,00 & $265,01 * *$ & 0,7 & 0,01 & $86,07 * * *$ & 0,4 & 0,01 & $57,31 * * *$ \\
\hline $\mathrm{S}_{7}$ & 0,58 & 0,01 & $66,30 * * *$ & 0,5 & 0,00 & $133,89 * *$ & 0,7 & 0,01 & $138,09 * *$ & 0,5 & 0,01 & $102,84^{* *}$ \\
\hline $\mathrm{S}_{8}$ & 0,74 & 0,01 & $100,16^{* *}$ & 0,5 & 0,01 & $88,27 * * *$ & 0,4 & 0,01 & $75,49 * * *$ & 0,2 & 0,01 & $52,01 * * *$ \\
\hline $\mathrm{S}_{9}$ & 0,15 & 0,01 & $13,16^{* * *}$ & 0,1 & 0,01 & $9,54 * * *$ & 0,4 & 0,01 & $38,63 * * *$ & 0,3 & 0,01 & $25,40 * * *$ \\
\hline
\end{tabular}
Kareler Ortalaması

Tablo 5 incelendiğinde ihracat kümelemesinde S2 değişkeni açısından küme ortalamaları arasında anlamlı bir fark olmadığı, bunun haricinde ithalat ve ihracat verileri için diğer kümelemelerde değişkenlerin anlamlı etkiye sahip olduğu görülmektedir.

Ward ve k-ortalama yöntemiyle yapılan kümeleme analizi sonuçlarına göre genel olarak Türkiye'ye uzak veya düşük nüfuslu ülkeler aynı kümede yer almaktadır. Bu ülkelerin Türkiye ile dış ticaret yoğunluğu düşüktür. Türkiye ve Rusya arasında enerji bağlamında gerçekleşen ticaretin sonucu olarak Rusya, ithalat kümelemesinde tek başına bir küme oluşturmuştur. Almanya ve Çin ise özellikle kimya sanayi, işlenmiş mal, makine, taşıt mal sınıfları başta olmak üzere Türkiye'nin ithalatının \%23,62'sini oluşturmaktadır. Ihracat kümelemesinde tek başına bir küme oluşturan Irak'a Türkiye ağırlıklı olarak işlenmiş mal, tekstil, mobilya, kuyum eşyası vb. ihraç etmektedir. Ayrıca ayrı bir küme altında yer alan Almanya, ABD, Birleşik Krallık ve İtalya'nın Türkiye'nin tüm ihracatı üzerindeki payı \%27,98'dir.

\section{Sonuç}

Gelişmekte olan ülkeler arasında yer alan Türkiye'nin daha iyi bir refah düzeyini yakalayabilmesi için dış ticaretini kendi lehine geliştirmesi gerekmektedir. Bu bağlamda Türkiye'nin 2016 yılı dış ticaret kümelemesinin incelendiği bu çalışmada, Türkiye'nin ithalatta enerji açısından dışa bağımlılığının ve ihracatta katma değeri düşük ürün pazarlamasının etkilerinin olduğu görülmüştür.

Çalışmada kullanılan Ward ve k-ortalama kümeleme yöntemleri sonuçları incelendiğinde genel olarak Türkiye'nin ithalatında Almanya, ABD, Birleşik Krallık, Çin, Brezilya ve Rusya'nın; ihracatında ise Almanya, Fransa, İran, İsrail, İtalya, Hollanda, Suudi Arabistan, İspanya, BAE, Mısır, Birleşik Krallık, ABD ve Irak'ın diğer ülkelerden ayrıştığı ifade edilebilir. Bu ülkelerden ihracatta Irak, ithalatta ise Rusya tek başına birer küme oluşturmaktadır. 
Ihracat ilk kümesinde Türkiye'ye mesafe olarak uzak veya küçük nüfus ve yüzölçümüne sahip ülkeler yer almaktadır. Bu kümede Avusturya, Hırvatistan, Çekya, Danimarka, Finlandiya, Yunanistan, İrlanda, Macaristan, Litvanya, Letonya, Portekiz, Slovakya, İsveç, İzlanda, Malta gibi Avrupa Birliği üyesi ülkeler de bulunmaktadır. Ayrıca Bosna-Hersek, Arnavutluk, Makedonya gibi Türkiye'nin tarihi bağlarının olduğu ülkeler de yine bu kümede yer almaktadır. Bu durum Türkiye'nin düşük yoğunluklu dış ticaret ilişkisinde olduğu bu ülkelere, daha fazla ihracat yapabilecek potansiyele sahip olduğu şeklinde yorumlanabilir. İkinci kümede ise Azerbaycan, Belçika, Bulgaristan, Çin, Fransa, Gürcistan, İsrail, İtalya, Güney Kore, Fas, Hollanda, Polonya, Romanya, Rusya, Suudi Arabistan, İspanya, İsviçre, Suriye, Birleşik Arap Emirliği (BAE), Mısır, Hollanda, Cezayir, Türkmenistan, Özbekistan yer almaktadır. Bu küme ağırlıklı olarak Türkiye'nin Rusya, Çin gibi yüksek ithalat yaptığı ülkelerden oluşmaktadır. Üçüncü kümede Almanya, İran, Birleşik KralIık ve ABD bulunmaktadır. Bu kümede İran dışındaki diğer ülkeler gelişmiş ülkelerdir. Son kümede ise Irak yer almaktadır. Türkiye, Irak'a ağırlıklı olarak işlenmiş mal ve giyim, mobilya, kuyum eşyası gibi çeşitli mamul eşya ihraç etmektedir.

Ithalat verileri için Ward ve k-ortalama yöntemleriyle yapılan kümeleme analizi sonucunda genel olarak ilk kümede Türkiye'nin düşük ithalat hacmine sahip olduğu ülkelerin bulunduğu görülmüştür. Bu kümede Türkiye'nin ihracatında önemli yere sahip İan ve Irak'ta bulunmaktadır. İthalat kümelemesinde ABD, Birleşik Krallık, Brezilya ve Hollanda ikinci kümeyi, Almanya ve Çin üçüncü kümeyi, Rusya ise son kümeyi oluşturmaktadır. Son üç kümede yer alan bu ülkelerden Birleşik Krallık ve Hollanda haricindeki ülkeler Türkiye'nin dış ticaret açığı verdiği ülkelerdir. Türkiye 2016 yılında Rusya ile enerji, Çin ile işlenmiş mal, makine, taşıt araçları bağlamında ağırlıklı olarak ithalat gerçekleştirmiştir.

Sonuçlar genel olarak değerlendirildiğinde Türkiye'nin en çok ithalat yaptığı ülke olan Çin ile ihracat hacminin çok düşük olması dikkat çekmektedir. Benzer durumun söz konusu olduğu Rusya dikkate alındığında, Türkiye'nin enerji sorununu çözebilmesi durumunda Rusya ile olan dış ticaretini kendi lehine çevirebileceği ifade edilebilir. Ayrıca katma değeri yüksek malların ihracatına önem verilmesinin Türkiye'nin geleceği açısından faydalı olacağı anlaşılmaktadır.

Çalışmanın dış ticaret konusunda yapılacak araştırmalara bakış açısı kazandırması ve Türkiye'nin dış ticarette geliştireceği perspektiflere katkı sağlaması beklenmektedir. Konu ile ilgili yapılacak sonraki çalışmalarda endüstri içi ticaret ya da belli sektörler açısından değerlendirmelerin yapılması önerilmektedir. 


\section{Kaynaklar}

Akpınar, Haldun (2014). Data Veri Madenciliği Veri Analizi, 1. Baskı, İstanbul: Papatya Yayıncılık.

Akyüz, Kadri Cemil (2006), “Avrupa Birliği Sürecinde Türkiye Orman Ürünleri Sanayinin Rekabet Düzeyi”, ZKÜ Bartın Orman Fakültesi Dergisi, C. 8, S. 9: 83-94.

Alpar, Reha (2013). Çok Değişkenli Istatistiksel Yöntemler,4. Baskı, Ankara: Detay Yayıncılık.

Aydın, Noyan; Seven, Ayşe Nur (2015), “il Nüfus Ve Vatandaşlık Müdürlüklerinin İş Yoğunluğuna Göre Hibrid Kümeleme İle Sınıflandırılması”, Yönetim ve Ekonomi Araştırmaları Dergisi, C. 13, S. 2: 181-201.

Bircan, Hüdaverdi, Zontul, Metin; Yüksek A. Gürkan (2006), “SOM Tipinde Yapay Sinir Ağlarını Kullanarak Türkiye’nin İhracat Yaptığı Ülkelerin Kümelenmesi Üzerine Bir Çalışma”, Atatürk Üniversitesi Iktisadi ve Idari Bilimler Dergisi, C. 20, S. 2: 219-239.

Bulum, Ahmet; Ersöz, Filiz; Ersöz, Taner (2013), “Dünya Ticaret Örgütü (WTO) Üyesi Ülkelerin Uluslararası Ticaret Hacimleri Üzerine Bir Çalışma”, Nevşehir Bilim ve Teknoloji Dergisi, C. 2, S. 2: 153-165.

Çokluk, Ömay, Şekercioğlu, Güçlü; Büyüköztürk, Şener (2014), Sosyal Bilimler Için Çok Değişkenli İstatistik: SPSS ve LISREL Uygulamaları, 3. Baskı, Ankara: Pegem Akademi Yayıncılık.

Hair, F. Joseph; Black, William C.; Babin, Barry J.; Anderson, Rolph E. (2014). Multivariate Data Analysis, 7. Baskı, Harlow: Pearson Education Limited.

Kantar, E., Deviren, B. \& Keskin, M. (2011), “Hierarchical Structure of Turkey’s Foreign Trade”, Physica A Journal, S. $390:$ 3454-3476.

Özdamar, Kazım. (2013), Paket Programlar ile istatistiksel Veri Analizi Cilt 2, 9. Baskı, Ankara: Nisan Kitabevi.

Seyidoğlu, Halil (2007), Uluslararası İktisat: Teori, Pratik Ve Uygulama, 16. Baskı, İstanbul: Güzem Can Yayınları.

Tatlıdil, Hüseyin (2002), Uygulamalı Çok Değişkenli Istatistiksel Analiz, Ankara: Ziraat Matbaacılık.

Tiryaki, Sebahattin; Aydın, Aytaç; Üçüncü, Kemal (2015), “Türkiye Mobilya Sektörünün Avrupa Birliği Sürecinde Dış Ticaret Durumunun Kümeleme Analizi İle İncelenmesi”, Selçuk Teknik Dergisi, özel sayı -1(UMK-2015): 938-949.

Uygur, S. (2013), “Ülkemizin Dış Ticaret Ve Doğrudan Yurt Dışı Yatırımlarında Tercih Ettiği Ülkeler İçin Rank Korelasyonu ve Kümeleme Analizi”, Uludağ Üniversitesi iktisadi ve Idari Bilimler Fakültesi Dergisi, C. 32, S. 2, 95-112.

TUiK, www.tuik.gov.tr/PrelstatistikTablo.do?istab_id=621,(Erişim Tarihi: 16.04.2016).

BM Uluslararası Ticaret İstatistikleri Veritabanı, https://comtrade.un.org/data, (Erişim Tarihi: 16.03.2017). 
Eskişehir Osmangazi Üniversitesi iiBF Dergisi 